\title{
Inventarisasi Penyakit Tanaman Pisang Koleksi Kebun Plasma Nutfah, Cibinong Science Center-BG
}

\section{Inventarisation of Banana Plant Diseases in Germplasm Collection Garden, Cibinong Science Center-BG}

\section{Riastiwi I}

Divisi Botani, Pusat Penelitian Biologi, Lembaga Ilmu Pengetahuan Indonesia, Cibinong 16911

Riastiwi I. 2017 - Inventarisasi Penyakit Tanaman Pisang Koleksi Kebun Plasma Nutfah, Cibinong Science Center. Jurnal Mikologi Indonesia 1(1). 38-44.

\begin{abstract}
Abstrak
Kebun Plasma Nutfah Pisang Cibinong Science Center (CSC) merupakan koleksi pisang hasil dari eksplorasi ke seluruh wilayah Indonesia. Koleksi ini kemudian diperbanyak untuk penelitian lebih lanjut. Dalam proses pengelolaannya monitoring kesehatan tanaman pisang perlu dilakukan untuk meningkatkan kualitas koleksi tersebut. Untuk keperluan tersebut dilakukan inventarisasi terhadap jenis-jenis penyakit yang menyerang tanaman koleksi, dengan harapan untuk mempertahankan kualitasnya sebagai bahan dasar penelitian lebih lanjut. Penelitian diawali dengan (1) Identifikasi kerusakan tanaman pisang dengan menggunakan hasil modifikasi metode Forest Health Monitoring (FHM), kemudian dilanjutkan dengan (2) mengukur intensitas serangan dan luas serangan pada tanaman pisang. Hasil penelitian menunjukkan bahwa koleksi pisang di kebun plasma nutfah CSC terserang penyakit Layu Fusarium (2,9\%), penyakit bercak Cordana (2\%), penyakit Black Sigatoka $(5,62 \%)$ dan penyakit Yellow Sigatoka $(4,68 \%)$. Luas serangan terjadinya penyakit sebesar 30,89\%.
\end{abstract}

Kata kunci - CSC - inventarisasi - penyakit pisang - plasma nutfah

\begin{abstract}
Banana Germplasm Gardens of Cibinong Science Center(CSC) was banana plants collection obtained from exploration in all area of Indonesian. This plant collection were propagated for further research. In the management process, monitoring of banana plant health needs to be undertaken to improve the quality of the collections. The aim of this study was to determine the types of diseases affecting the banana plant collection with the purpose of maintaining its quality as the principal material for further research. Research was started by (1) iden-tification of banana plant damageusing themodified method of Forest Health Monitoring (FHM) and (2) measuring the intensity and area of the attacks on the banana plant.The results showed that the banana plant collection in the CSC garden were attacked by Fusarium wilt (2.9\%), Cordana spot disease (2\%), Black Sigatoka disease (5.62\%) and Yellow Sigatoka (4.68\%) disease. The percentage of disease incidence was $30.89 \%$.
\end{abstract}

Key words - banana diseases - CSC - inventarisation - germplasm 


\section{Pendahuluan}

Pisang (Musa spp.) merupakan salah satu komoditas buah yang banyak dikonsumsi oleh masyarakat. Buah pisang memiliki kandungan gizi yang cukup tinggi meliputi karbohidrat, gula, protein, lemak, vitamin A, B, dan C serta garam-garam mineral. Indonesia termasuk negara yang menduduki peringkat keenam dari sepuluh besar penghasil buah pisang di dunia dan menyumbang sekitar $30 \%$ dari produksi buah-buahan dalam negeri. Sementara ini, untuk menunjang devisa negara, pemerintah menargetkan produksi pisang pada tahun 2025 sebesar 11.266.000 ton (Kementerian Pertanian, 2012).

Pada tahun 2012 total produksi pisang dalam negeri baru sebesar 6,189,052 ton yang hampir seluruhnya hanya untuk memenuhi kebutuhan dalam negeri. Sedangkan untuk memenuhi kebutuhan ekspor, jumlahnya relatif masih sedikit dan bahkan mengalami penurunan. Penurunan ini terkait dengan produktivitas, terutama masalah kualitas buah yang tidak memenuhi persyaratan untuk ekspor. Indikasi yang menyebabkan penurunkan kualitas adalah persoalan hama dan penyakit pada saat pertumbuhannya. Menurut Sulyanti et al (2011), Jumjunidang et al (2012) dan Prasetyo \& Sudiono (2004) pada umumnya penyakit yang menyerang tanaman pisang di Indonesia antara lain disebabkan oleh penyakit layu fusarium, penyakit black sigatoka, penyakit yellow sigatoka, penyakit bercak cordana, penyakit layu bakteri, dan penyakit bunchy top.

Mengingat banyaknya jenis penyakit serta dampaknya terhadap produktivitas dan kualitas buahnya, maka diperlukan perhatian yang serius untuk penanganannya. Untuk kepentingan tersebut, Pusat Penelitian Biologi-LIPI telah melakukan eksplorasi dan inventarisasi kekayaan dan keanekaragaman jenis pisang dari seluruh Indonesia untuk disimpan sebagai koleksi plasma nutfah di kebun plasma nutfah Cibinong Science Center (CSC). Koleksi ini dijadikan sebagai bahan penelitian lebih lanjut untuk mendapatkan kultivar buah yang memiliki kualitas dan produktivitas untuk dikembangkan sebagai tanaman budidaya. Sementara ini beberapa diantaranya telah dilakukan karakterisasi (Poerba \& Ahmad, 2010a, 2010b). Sementara ini untuk tujuan pemuliaan, yang biasa dilakukan adalah dalam rangka mendapatkan jenis pisang yang memiliki keunggulan dari segi bobot tandan, bobot buah, kualitas buah (kandungan karbohidrat) dan ketahanannya terhadap penyakit.

Terkait dengan upaya untuk menjaga kualitas pertanaman koleksi plasma nutfah milik Pusat Penelitian Biologi-LIPI yang berasal dari lingkungan dan daerah asal yang berbedabeda, perlu segera dilakukan monitoring terhadap beberapa jenis hama dan penyakit yang menyerang pada koleksi. Dengan diinventarisasi jenis-jenis penyakit yang menyerang setiap individu koleksi, diharapkan dapat dijadikan sebagai dasar dalam pengelolaan kebun koleksi plasma nutfah pisang yang dimiliki Pusat Penelitian Biologi-LIPI, terutama untuk kepentingan penelitian lebih lanjut yang mengarah pada pemuliaan.

\section{Metoda Penelitian}

\section{Lokasi dan Waktu Penelitian}

Penelitian dilakukan di Kebun Plasma Nutfah Pisang CSC yang luasnya mencapai 3,5 hektar. Tanaman pisang yang diamati berjumlah 560 individu tanaman.

\section{Penilaian tingkat kerusakan secara visual}

Penelitian ini menggunakan metode hasil modifikasi Metode Pemantau Kesehatan Hutan atau Forest Health Monitoring (FHM). Metode ini memfokuskan pada penilaian tingkat kesehatan melalui pengelompokkan jenis dan tingkat kerusakan per-individu tanaman (Alexander \& Barnad, 1995). Pengamatan dilakukan secara visual terutama terhadap gejala kerusakan pada setiap bagian tanaman pisang. Gejala yang dimaksud adalah karakteristik 
yang muncul pada tanaman sebagai hasil interaksi patogen dengan tanaman tersebut contohnya layu dan bercak pada daun (Semangun, 2006).

Cara pengamatan yaitu dengan mengamati tanaman dari seluruh arah. Tanda dan gejala kerusakan diberi prioritas dan dikumpulkan berdasarkan titik pengamatan menurut urutan: akar, batang, bunga, buah dan daun. Sementara itu beberapa jenis penyakit yang sering dijumpai, menurut Sulyanti et al (2011) tersaji pada Tabel 1. Kemudian untuk melakukan penilaian terhadap kerusakan pada sampel ditentukan berdasarkan pada gejala kerusakan dan intensitas penyakit.

Tabel 1. Jenis penyakit dan gejala khas yang ditimbulkan pada tanaman pisang.

\begin{tabular}{cll}
\hline Kode & Jenis Penyakit & \multicolumn{1}{c}{ Gejala khas } \\
\hline 1 & Layu Fusarium & $\begin{array}{l}\text { Daun menguning, layu dan kering dimulai dari } \\
\text { daun yang tertua }\end{array}$ \\
\hline 2 & Yellow Sigatoka & $\begin{array}{l}\text { Munculnya bercak-bercak pada daun yang } \\
\text { teratur pada garis lurus }\end{array}$ \\
\hline 3 & Black Sigatoka & $\begin{array}{l}\text { Munculnya bercak hitam kecil yang dikelilingi } \\
\text { warna kuning kemudian melebar }\end{array}$ \\
\hline 4 & Layu Bakteri & Munculnya garis-garis coklat pada tulang daun \\
\hline 5 & Cordana & Munculnya bercak bulat telur kemudian melebar \\
\hline 6 & Bunchy top & $\begin{array}{l}\text { Ditandai dengan munculnya garis-garis hijau } \\
\text { yang terputus-putus pada tulang daun }\end{array}$ \\
\hline
\end{tabular}

Selanjutnya tingkat keparahan gejala penyakit setiap sampel diberi nilai (skor) berdasarkan kenampakan keseluruhan setiap individu tanaman menggunakan modifikasi pedoman dari Alexander \& Barnard (1995) yaitu dinilai:

$0=$ jika individu tersebut sehat (tidak ada gejala maupun tanda penyakit)

$1=$ jika $>0-25 \%$ bagian tanaman menunjukkan gejala dan atau tanda penyakit.

$2=$ jika $>26-50 \%$ bagian tanaman menunjukkan gejala dan atau tanda penyakit.

$3=$ jika $>51-75 \%$ bagian tanaman menunjukkan gejala dan tanda penyakit.

$4=$ jika $>76-100 \%$ bagian tanaman menunjukkan gejala dan atau tanda penyakit.

\section{Luas serangan (LS) dan Intensitas penyakit (IP)}

Persentase kerusakan dihitung dengan menggunakan modifikasi rumus (Chester 1959) :

$$
\mathrm{LS}=\frac{\sum \mathrm{N}_{\mathrm{i}}}{\sum \mathrm{N}_{\mathrm{o}}} \times 100 \% \mathrm{IP}=\frac{\sum\left(\mathrm{n}_{\mathrm{i}} \times \mathrm{z}_{\mathrm{i}}\right)}{\mathrm{N}_{\mathrm{o}} \times \mathrm{Z}} \times 100 \%
$$

Keterangan:

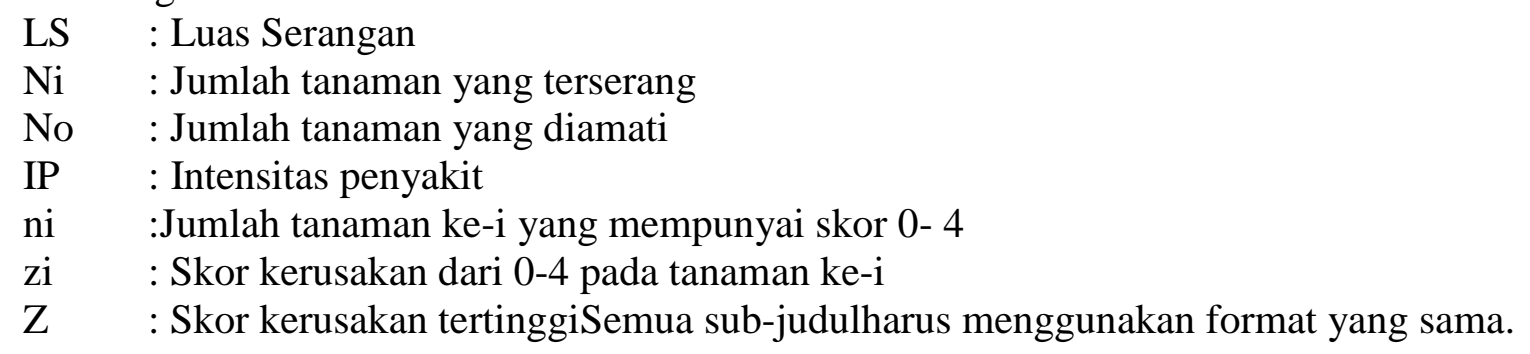

\section{Hasil}

Tercatat sebanyak empat jenis penyakit utama yang menyerang individu koleksi plasma nutfah pisang milik Pusat Penelitian Biologi-LIPI di CSC. Jenis-jenis tersebut yaitu penyakit Layu Fusarium menyerang sebesar 2,9\% (25 individu) dari total sampling yang jumlahnya 560 individu. Kemudian disusul penyakit bercak Cordana sebesar $2 \%$ (28 individu), penyakit Black Sigatoka sebesar 5,62\% (61 individu) dan penyakit Yellow Sigatoka 4,68\% 
(59 individu) (Tabel 2). Keempat jenis penyakit ini juga pernah dilaporkan oleh Sulyanti et al. (2011) sebagai jenis penyakit yang umum ditemukan pada pertanaman pisang. Penyakit layu fusarium umumnya menyerang baik pada bagian akar, batang dan daun. Sedangkan Black Sigatoka, Cordanadan Yellow Sigatoka hanya menyerang pada daun saja.
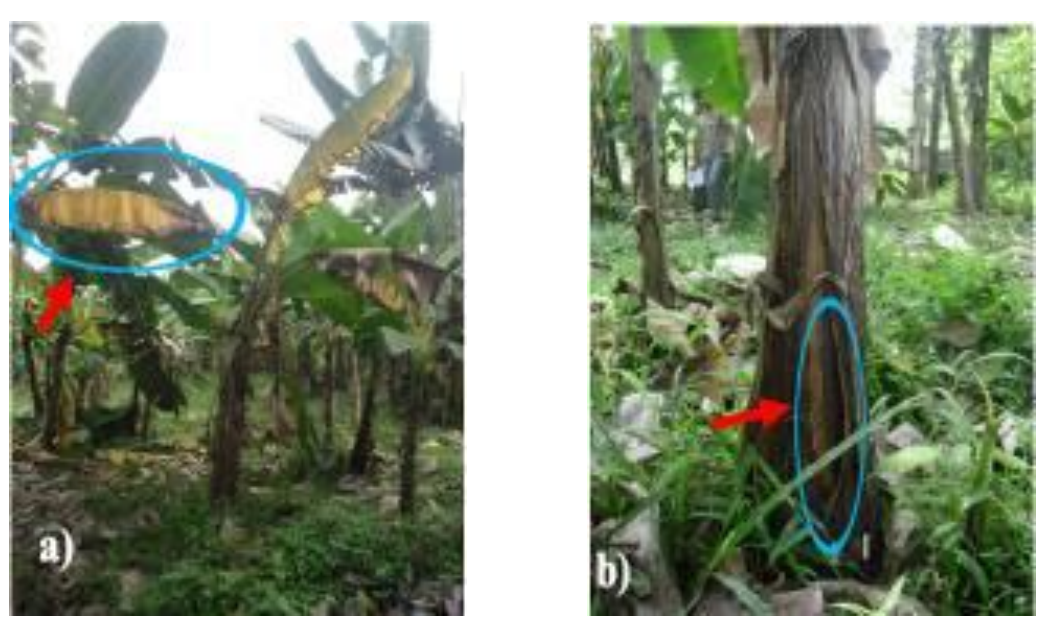

Gambar 1a-b. Gejala penyakit layu Fusarium.
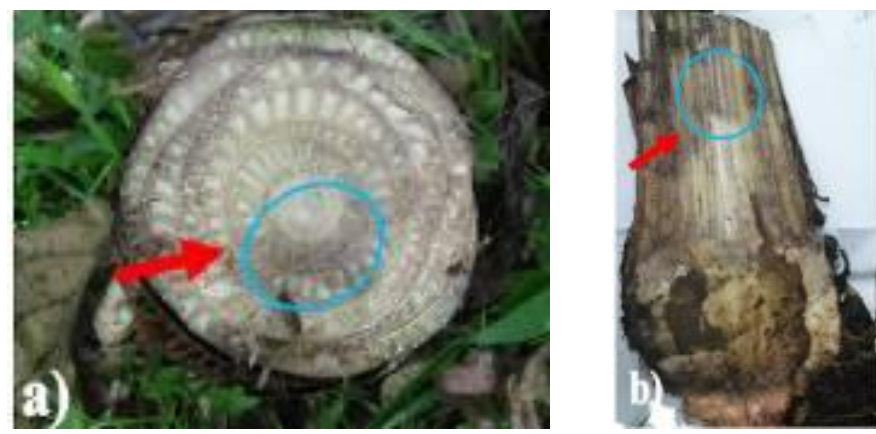

Gambar 2a-b. Penampang melintang dan membujur tanaman pisang yang terdeteksi penyakit layu fusarium.

Tabel 2 Persentase intensitas serangan penyakit.

\begin{tabular}{|c|c|c|c|c|c|c|c|c|c|c|}
\hline \multirow{2}{*}{ Jenis Penyakit } & \multirow{2}{*}{\multicolumn{2}{|c|}{ Skor }} & & & \multirow[t]{2}{*}{$\mathrm{Ni}(\%)$} & \multirow[t]{2}{*}{ IP } & \multicolumn{4}{|c|}{ Bagian yang menunjukkan gejala } \\
\hline & & & & & & & Akar & Batang & Daun & \\
\hline Cordana & 14 & 12 & 1 & 1 & $28(5)$ & 2 & - & - & & $\checkmark$ \\
\hline Layu fusarium & 2 & 10 & 9 & 4 & $25(4,5)$ & 2,9 & $\checkmark$ & $\checkmark$ & & $\checkmark$ \\
\hline Yellow Sigatoka & 22 & 30 & 5 & 2 & $59(10,5)$ & 4,68 & - & - & & $\checkmark$ \\
\hline Black Sigatoka & 17 & 24 & 15 & 5 & $61(10,9)$ & 5,62 & - & - & & $\checkmark$ \\
\hline Total & 55 & 76 & 30 & 12 & $173(30,8)$ & & & & & \\
\hline Persentase skor (\%) & 9,8 & 13,6 & 5,4 & 2,1 & & & & & & \\
\hline
\end{tabular}

Keterangan: Ni : Jumlah tanaman yang terserang

IP : Intensitas Penyakit 

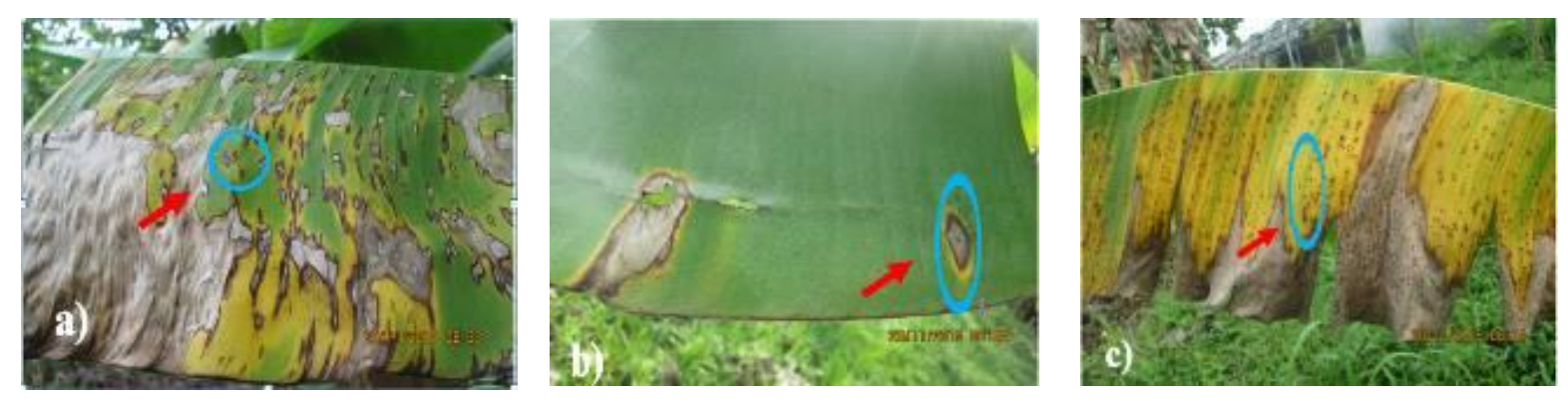

Gambar 3a-c. Gejala penyakit Black Sigatoka (a); Bercak Cordana (b) dan Yellow Sigatoka (c).

\section{Pembahasan}

\section{Penyakit Layu Fusarium}

Penyakit layu fusarium merupakan penyakit tanaman pisang yang sampai saat ini masih menjadi masalah utama dalam perkebunan pisang. Hal ini juga ditunjukkan dari hasil penelitian ini bahwa layu fusarium menyerang pada seluruh bagian tanaman (akar, batang, dan daun). Oleh karena itu tidak mengherankan jika banyak varietas pisang yang rentan terhadap penyakit ini. Hasil penelitian Jumjunidang et al. 2012, menyebutkan bahwa penyakit layu fusarium pada umumnya menyerang varietas pisang Barangan, Kepok, Raja dan Siem.

Hasil pengamatan menunjukkan bahwa gejala yang muncul diawali dengan daun menguning, layu dan kering yang dimulai dari daun yang tertua (Gambar 1a) dan batang mulai pecah (Gambar 1b). Hal ini diperkuat hasil penelitian Dita et al. (2010) yang menyatakan bahwa gejala layu fusarium adalah penguningan daun tertua. Tanaman pisang yang terkena penyakit layu fusarium pada gejala lanjut akan nampak daun mulai menguning secara menyeluruh dan kemudian akhirnya layu dan mati. Apabila batang palsu ini dibelah membujur (Gambar 2a) dan melintang (Gambar 2b) maka akan terlihat garis-garis berwarna ungu pada permukaan jaringan pembuluh batang. Penyakit layu fusarium ini disebabkan oleh Fusarium oxysporum f. sp. cubense (Loekas et al. 2012).

Intensitas penyakit layu fusarium sebesar $2,9 \%$ hal ini menunjukkan bahwa penyakit ini belum menjadi penyebab utama kerusakan pada koleksi plasma nutfah pisang Pusat Penelitian Biologi-LIPI, namun tetap harus diwaspadai karena juga berpotensi menjadi kerusakan yang tinggi. Gejala yang muncul tampak pada akar, batang dan daun (Tabel 2) hal ini dikarenakan patogen penyebab penyakit ini merupakan patogen tular tanah. Patogen menginfeksi melalui akar, terutama akar yang terluka kemudian menyerang jaringan pembuluh pada batang dan akhirnya daun menguning. Penyebaran melalui tanah karena inokulumnya sudah ada dalam tanah, mengingat jamur penyebab penyakit ini dalam fase klamidospora yang mampu bertahan dalam tanah pada jangka waktu yang lama (Stover, 1962). Pada kondisi lingkungan yang lembab sehingga mendukung proses infeksi pada tanaman pisang. Tanaman pisang yang telah terindikasi terkena penyakit layu fusarium harus segera disanitasi agar tidak menular pada tanaman pisang disekitarnya.

\section{Penyakit Black Sigatoka}

Gejala awal ditandai dengan adanya bercak hitam kecil yang dikelilingi oleh warna kuning muda yang kemudian semakin lama melebar dan daun mengering (Gambar 3a). Hal ini sesuai dengan Feakin (1971), bahwa gejala awal terlihat dengan lesi kecil pada daun, lesi ini berwarna kuning pucat, gelap, semakin luas membentuk bintik-bintik cokelat. Pada gejala lanjut tanaman pisang yang terkena penyakit Black Sigatoka daunnya mengering hampir diseluruh 
permukaan daun, kemudian perlahan akan mati. Intensitas penyakit Black Sigatoka lebih tinggi dari penyakit layu fusarium yakni sebesar $5,62 \%$. Hal ini dikarenakan patogen yang menyebabkan penyakit ini merupakan patogen yang menyebar melalui udara. Penyakit Black Sigatoka disebabkan oleh Mychospaerella fijiensis var difformis Mulder (Sulyanti et al. 2011). Pisang Ambon, Telor, Barangan, Emas dan Telor merupakan beberapa jenis pisang yang rentan terkena penyakit black sigatoka (Sahlan dan Soemargono, 2011).

\section{Penyakit Bercak Cordana}

Gejala yang muncul pada daun diawali dengan bercak-bercak bulat telur. Kemudian bercak tersebut melebar dikelilingi oleh lingkaran yang berwarna kuning cerah (Gambar 3b). Daun yang lebih tua pusat bercaknya mengering, berwarna kelabu muda dengan tepinya berwarna coklat tua dan dikelilingi oleh lingkaran berwarna kuning cerah (Arsensi \& Rofik, 2015). Penyakit bercak Cordana disebabkan oleh Cordana musae (Zimm) (Loekas et al. 2012). Intensitas kerusakan penyakit ini adalah sebesar 2\%. Apabila dibandingkan penyakit lainnya penyakit ini merupakan intensitas terendah. Hal ini dikarenakan tingkat virulensi patogen penyebab penyakit ini lebih rendah dibanding patogen lainnya.

\section{Penyakit Yellow Sigatoka}

Gejala awal yang muncul adanya bintik-bintik kecil yang berwarna kuning pucat pada pangkal daun yang teratur pada garis lurus atau sejajar dengan tulang-tulang daun. Bintikbintik melebar menjadi bercak kuning tua kemerahan sampai kehitaman dan akhirnya mengering (Gambar 3c). Sulyanti et al (2011) menyebutkan bahwa penyakit ini tidak menyebabkan kematian akan tetapi pada gejala lanjut daun mengering sehingga mengganggu proses fotosintesis yang akan berdampak pada pengisian buah dan anakan. Tanaman pisang yang terserang sebesar 4,68\% dikarenakan penyebab penyakit ini menyebar melalui udara. Penyakit Yellow Sigatoka disebabkan oleh Mycosphaerella musicola Mulder. Rocha et al (2012), menyatakan bahwa Yellow Sigatoka menunjukkan dua puncak keparahan ekstrim. Dimana terjadi selama musim hujan dan musim kemarau disebabkan oleh tingginya konsentrasi spora di udara.

Berdasarkan penelitian yang telah dilakukan, dijumpai luas serangan sebesar $30,89 \%$ yang menunjukkan bahwa pengelolaan kebun plasma nutfah pisang masih belum optimal. Hal ini dikarenakan kebun plasma nutfah pisang ini telah mengalami beberapa rotasi tanam, sehingga mudah terserang oleh patogen penyebab penyakit. Quirino et al (2014) menyatakan setelah rotasi tanam kedua dan ketiga, pada tanaman pisang, meningkatkan inokulum patogen penyebab penyakit.

Hasil penelitian diperoleh empat penyakit tanaman pisang yang menyerang koleksi Kebun Plasma Nutfah pisang yaitu penyakit Layu Fusarium dengan rata-rata persentase serangan 2,9\%, penyakit bercak Cordana 2\%, penyakit Black Sigatoka 5,62\% dan penyakit Yellow Sigatoka 4,68\%. Secara keseluruhan luas serangan tanaman pisang yang terkena penyakit adalah sebesar 30,89\%.

\section{Ucapan Terima Kasih}

Terima kasih kepada Kepala Pusat Penelitian Biologi, Kepala Bidang Botani Pusat Penelitian Biologi dan Dr. Yuyu S. Poerba yang telah memberikan ijin pengambilan sampel di Kebun Plasma Nutfah Pisang CSC-BG di bidang Botani, Pusat Penelitian Biologi, LIPI. 


\section{Pustaka}

Alexander SA and Barnard JE. 1995. Forest Health Monitoring: Field Methods Guide, Enviromental Monitoring System Laboratory, Las Vegas.

Arsensi I and Rofik A. 2015. Inventarisasi dan Identifikasi Cendawan Patogen pada Tanaman Pisang Rutai (Musa borneensis). Zira'ah 40: 129-139.

Chester KS. 1959. How Sich is The Plant? In: Horsfall JG, Diamond AF. (eds). Plant Pathology Press, New York : London.

Dita MA, Waalwijk C, Buddenhagen IW, Souza Jr. MT and Kema GHJ. 2010. A Molecular Diagnostic for Tropical Race 4 of the Banana Fusarium Wilt Pathogen. Plant Pathology 59: 348-359.

Feakin SD. 1971. Pest Control in Bananas Pans Manual No.1. London. England.

Jumjunidang, Edison, Riska, dan Hermanto C. 2012. Penyakit Layu Fusarium pada Tanaman Pisang di Provinsi NAD. Sebaran dan Identifikasi Isolat berdasarkan Analisis Vegetative Compatible Group. J. Hortikultura 22: 165-172.

Kementerian Pertanian. 2012. Rencana Kinerja Tahunan Kementrian Pertanian 2012. http://www.pertanian.go.id/sakip/admin/data/RKT_KEMENTERIAN_PERTANI AN_2012.pdf.

Poerba YS dan Ahmad F. 2010a. Keragaman Genetik Kultivar Pisang Diploid (AA) Koleksi Cibinong Science Center Berdasarkan Marka RAPD dan ISSR. Biota 15: 308315.

Poerba YS dan Ahmad F. 2010b. Genetic variability among 18 cultivars of cooking bananas and plantain by RAPD and ISSR markers. Biodiversitas 11: 118-123.

Prasetyo J dan Sudiono. 2004. Pemetaan persebaraan penyakit bunchy top pada tanaman pisang di provinsi Lampung. J.HPT Tropika 4: 94-101.

Quirino ZBR, Ledo AS, Talamini V, Oliveira LFM and Teixera KCS. 2014. Response of banana genotypes to yellow Sigatoka in coastal tablelands of Sergipe, Brazil. Revista Ciencia Agronomica 45: 209-213.

Rocha HS, Pozza EA, Ucho CN, Corderio ZJM, Souza PE, Sussel AB and Rezende CA. 2012. Embrapa Cassava and Fruits, Cruz das Almas, BA, Brazil Temporal Progress of Yellow Sigatoka and Aerobiology of Mycosphaerella musicola Spores. J Phytopathol. doi: 10.1111/j.1439-0434.2012.01897.x_2012 Blackwell Verlag GmbH.

Sahlan SA.2011. Distribution and Incidence Leaf Diseases of Banana in Several Banana Production Centers ini North Sumatra, West Sumatra Bengkulu and West Java. Agrivita 33: 026-053.

Semangun H. 2006. Pengantar ilmu penyakit tumbuhan. Gadjah Mada University Press, Yogyakarta.

Soesanto L, Mugiastuti E, Ahmad F dan Witjaksono. 2012. Diagnosis Lima Penyakit Utama karena Jamur pada 100 Kultivar Bibit Pisang. J. HPT Tropika 12: 36-45.

Sulyanti E, Liswarni Y dan Indri. 2011. Inventarisasi Penyakit Tanaman Pisang (Musa paradisiaca Linn.) berdasarkan Gejala di Kabupaten Tanah Datar. Manggaro 12: 49-54.

Stover RH. 1962. Fusarial Wilt (Panama Disease) of Bananas and Other MusaSpecies. CMI, Kew, Surrey, UK. 